\title{
Current and Emerging Therapies for the Management of Diabetic Retinopathy
}

\author{
Manodhini Elakkiya, Kousalya Selvaraj, Gowthamarajan Kuppuswamy* \\ Department of Pharmaceutics, JSS College of Pharmacy, Udhagamandalam, JSS University, Mysore, India.
}

\begin{tabular}{|c|c|}
\hline ARTICLE INFO & ABSTRACT \\
\hline $\begin{array}{l}\text { Article history: } \\
\text { Received on: } 25 / 05 / 2017 \\
\text { Accepted on: } 19 / 07 / 2017 \\
\text { Available online: 30/09/2017 }\end{array}$ & $\begin{array}{l}\text { Diabetes Mellitus (DM) has many complications, in which Diabetic Retinopathy (DR) is the major one. } \\
\text { Blindness among working age people was due to DR. Retinal angiogenesis and retinal vascular permeability is } \\
\text { the pathogenesis behind vision loss. Polyol pathway, protein kinase C (PKC) activation, renin angiotensin- } \\
\text { aldosterone system (RAAS), oxidative stress etc are the pathophysiological pathways which are discussed in this } \\
\text { review for better understanding. PKC inhibitors. anti-inflammatory agents. RAAS blockers anti-vascular }\end{array}$ \\
\hline $\begin{array}{l}\text { Key words: } \\
\text { Diabetic retinopathy, } \\
\text { Pathogenesis, current } \\
\text { therapies, emerging } \\
\text { therapies, Ocular } \\
\text { neovascularisation. }\end{array}$ & $\begin{array}{l}\text { Endothelial growth factor (VEGF) agents, antioxidants and fibrates which are the used for the better treatment } \\
\text { for DR is also elaborated in this review. }\end{array}$ \\
\hline
\end{tabular}

\section{INTRODUCTION}

DM is characterized by high levels of blood glucose which is the disorder of carbohydrate metabolism (King et al., 1998). Globally, 387 million people had diabetes in 2014 and its prevalence will increase to 592 million individuals by 2035 as per International Diabetes Federation (Diabetes Federation., 2014). According to World Health Organization (WHO) diabetes is defined as a chronic disease in which enough insulin was not produced by the pancreas or the body does not take enough insulin. DR was caused by a sustained increase in glucose level and consequences in minor vascular retinal vessels (Porta and Bandello, 2002). DR may be characterized by the hypoxia (abnormal blood vessel growth) in the retina (Rechtman et al., 2007). DR is not only chronic disease, but also it is a sight threatening disease of retinal vasculature (NICECKS., 2010).

\footnotetext{
* Corresponding Author

E-mail: gowthamsang @gmail.com
}

The pathogenesis behind this blindness may increase retinal vascular permeability and retinal angiogenesis. These changes are due to hypoxia and chronic hyperglycemia. If the diagnosis was done with proper timing and retinal laser treatment, blindness can be reduced in $90 \%$ patients. For avoiding DR and slowing down its progression, prevention of DM and good metabolic control is more important (ETDRS, 1991).

There are two different types of DR. Polyol pathway, non-enzymatic glycation, PKC, inflammatory, hemodynamic changes, growth factor, oxidative stress and renin angiotensin pathways are pathological pathways which leads to DR. DR can be also prevented by controlling blood sugar levels and blood pressure. Various approaches to treat DR are PKC inhibitors, RAAS inhibitors, Anti-VEGF inhibitors, Fibrates, antioxidants and anti-inflammatory agents as well. As conventional therapy has limitations for DR treatment there are certain therapies that are emerging for the treatment that includes laser therapy, vitrectomy and intra-vitreal injections of anti VEGF agents, corticosteroids and certain other pharmacological agents as well. 
In DR, combination therapy was used rather than monotherapy that intra-vitreal injection of one or two drugs has given to the patient who has undergone vitrectomy surgery for proliferative diabetic retinopathy (PDR). So there is a stronger support for combination therapies than monotherapy. This paper reviews about DR mechanisms, new emerging therapies and various approaches for the management of the disease.

\section{Pathogenesis of Diabetic Retinopathy}

DR may cause visual acuity (VA) because it is a microvascular complication of diabetes, which leads to vision loss. Increased blood sugar can damage retinal blood vessels. Swelling of retinal tissue and clouding of vision was due to leakage of blood and other fluids. Cotton wool spots, capillary closure, arterio venous shunts, neovascularisation, retinal haemorrhage, retinal exudates/oedema, lipid exudates and macular edema are the clinical symptoms of DR. Vascular permeability was also increased which leads to retinal thickening and loss of visual acuity. DR was managed by controlling hyperglycemia, hypertension and dyslipidemia. EDTRS classified DR as follows:

\section{Non-proliferative retinopathy (NPDR)}

It is more extensive than background retinopathy. Blood flow becomes restricted, but did not show any new blood vessel growth.

\section{Mild NPDR}

Micro-aneurysms (secular enlargement of the venous end of a retinal capillary)

Moderate NPDR: Between mild NPDR and severe NPDR

\section{Severe NPDR}

Severe intra-retinal haemorrhages and micro-aneurysms

\section{Proliferative retinopathy (PDR)}

Growth factors are the chemicals which are released when blood vessels of retina damages, this leads to growth of tiny blood vessels (proliferate) from the damaged blood vessels.

The major reason for DR complication is hyperglycemia. Metabolic dysfunction increased by high glucose level and other signalling pathways activation leads to DR progression. At present, DR represented by glycemic control which is the most effective medical treatment (Hudson, 1996; Aiello, 2003; Porta and Allione, 2004; Wang et al., 2009). There are Studies which showed that blood sugar level control is more important (Schaumberg et al., 2005; Kilpatrick et al., 2006). It was found that more recent pathogenesis behind diabetes complications are poly (ADP-ribose) polymerase (PARP), reactive oxygen and inflammatory cascade mechanisms are involved in the (Stratton et al., 2006). Rather than oxidative stress and PARP activation increased aldose reductase activity is a major cause in the pathogenesis of diabetes (Obrosova et al., 2005). There are many biochemical pathways involved in the DR progression. They may include: polyol pathway, non enzymatic glycation, PKC activation, hemodynamic changes, RAAS system, subclinical inflammation, leukostasis, oxidative stress and growth factors. Schematic diagram of pathogenesis of DR was shown in Fig1:

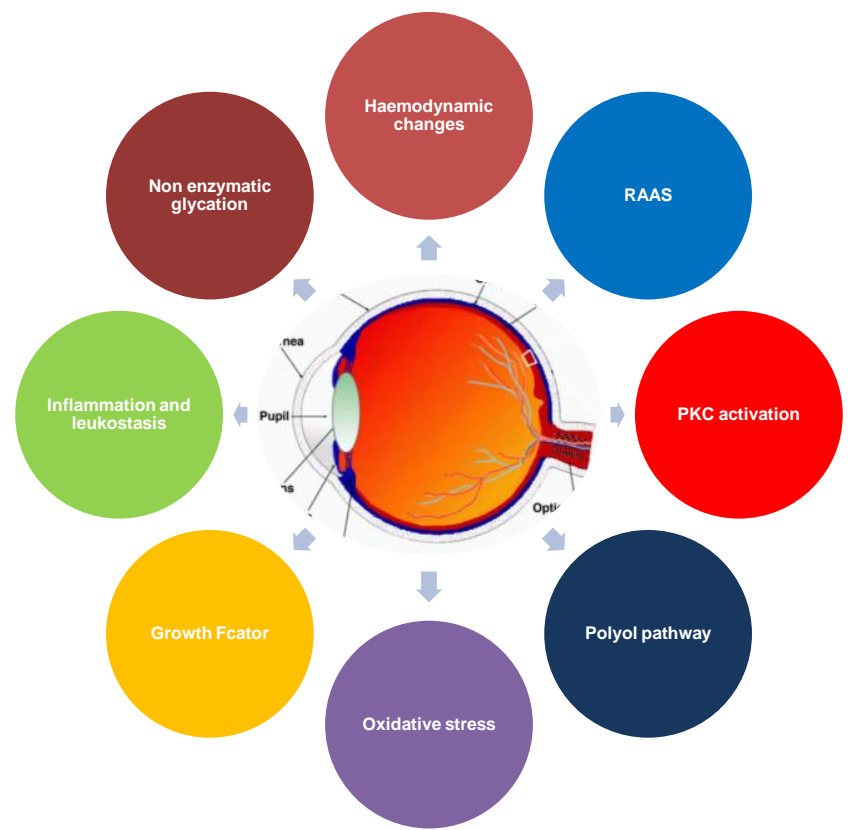

Fig. 1: Pathogenesis of DR.

\section{Polyol pathway}

Certain amount of glucose is metabolized in cellular metabolism by polyol pathway. Glucose flux is increased by this pathway in diabetes patients. Polyol pathway is controlled by the two steps. In the polio pathway, aldose reductase helps to reduce sorbitol from glucose using NADPH, and then sorbitol dehydrogenase is an enzyme that metabolizes sorbitol to fructose, which uses NAD+ as a cofactor (Dagher et al., 2004). If an excess of sorbitol in retinal vascular cells cause osmotic damage leads to DR. In order to predict individual susceptibility in retinopathy, aldose reductase gene polymorphisms may be helpful. Even though aldose reductase inhibitors (ARIs) have yielded incompatable results in DR of experimental animals polyol pathway has become a dread target (Hammes et al., 1991).

\section{Non-enzymatic protein glycation}

AGEs are important pathogenic mediators which reduce sugars, by non-enzymatic reaction. Diabetic patients have AGEs in their retinal vessel, same as in serum and retinopathy. Cells get affected by AGEs by three mechanisms: (a) adducts which is present on altered serum proteins, (b) glucose metabolism product endogenous adducts, and (c) ECM-immobilised structural modification of proteins. Amadori product is formed as a result of early glycation and oxidation. AGEs is generated by protein and lipid glycation. AGE formation and activation of AGE receptors represent important as per early experimental works. In DR, inhibition of these pathways with interconnected pathogenic mechanisms presents a valid avenue for therapeutic exploitation 
(Chibber et al., 1999; Stitt et al., 2002; Peppa et al., 2003; Wang et al., 2006; Zong et al., 2011).

\section{PKC Activation}

It helps in cell signalling. Hyperglycemia leads to increase in the de novo synthesis of di-acylglycerol (DAG), which causes major changes in endothelial permeability, hemodynamic changes, extracellular matrix protein synthesis, intracellular changes and VEGF production (Koya and King., 1998; Clarke and Dodson., 2007). The PKC $\beta 1 / 2$ isoform expression contributes to the loss of capillary pericytes. Inhibition of PKC only reduces the loss of vision, not for preventing DR (Simonson 1988).

\section{Hemodynamic changes}

The mechanism for DR progression has increased blood flow in the retina and loss of auto regulation. It has documented that the diabetic patients have a high incidence of hypertension (Kohner., 1993; Mancia., 2005). Hypertension contributes to DR progression by two mechanisms. First, the endothelial dysfunction occurs by mechanical stretch and shear stress on the endothelial cells (Berka., 2006). Second, regulation of blood pressure in the endocrine system was involved in the pathogenesis of DR (Funatsu et al., 2002).

\section{RAAS}

RAAS involved in the maintain body fluid balance and regulates blood pressure. During PDR, the expression of the receptors, signalling molecules of the RAAS and angiotensin receptors increases in the retina (Funatsu et al., 2002; Sjølie et al., 2008). The DR Candesartan Trials (DIRECT) and RASS both reported with the reduction of retinopathy progression (Van Hecke et al., 2005; Chaturvedi 2008; Mauer et al., 2009).

\section{Subclinical inflammation and leukostasis}

Retinal inflammation causes increased intraocular blood pressure eNOS, new blood vessels formation and VEGF leads to haemorrhages in the retina which causes increased permeability and leukostasis. (Lutty et al., 1997). Inflammation is due to increase in the serum concentration of cytokines, adhesion molecules and activation of immune cells (Schroder et al., 1991; Spijkerman et al., 2007; Klein et al., 2009).

In DR pathogenesis leukostasis leads to capillary occlusion and ROS associated apoptosis (Halliwell and Gutteridge., 1990).

\section{Oxidative stress}

Oxidative stress is lack of proportion between ROS production and ROS neutralization by antioxidants. The cellular components are damaged by oxidative stress and leads to the pathogenesis of many diseases. ROS are detoxified in normal physiological conditions (Mates et al., 1999). Increased oxidative species causes DR progression (Enden et al., 1995).

\section{Growth factors}

Growth factors which contribute DR development includes basic fibrobroblast growth factor (bFGF) (Armstrong et al., 1998), insulin-like growth factor-1 (IGF-1) (Hueber et al., 1996; Haurigot et al., 2009), angiopoietin- 1 and -2 (Patel et al., 2005; Berka et al., 2006; Rangasamy et al., 2011), stromal-derived factor-1 (Coxon et al., 2010), epidermal growth factor (EGF) (Lev-Ran et al., 1990), transforming growth factor-beta 2 (TGF$\beta \beta 2$ ) (Min et al., 2006), platelet-derived growth factors (PDGFs) (Praidou et al., 2009), and erythropoietin (Eckardt, 2009). Among these growth factors VEGF plays an important role in DR pathogenesis.

The DR leads to two visual complications, (i.e.,) diabetic macular edema (DME) and PDR. Standard treatments for DME and PDR are glycemic control and photocoagulation. In recent years, there are certain measures to avoid the risk for blindness which includes medical managements and ocular managements. An adjunctive pharmacologic therapy by anti-VEGF agents and triamcinolone acetonide shows better treatment for both PDR and DME. There are some new factors involved in the pathogenesis of DR, emerge to the new therapies.

\section{Currently approved therapies}

The therapies that are currently available for the management of DR. Laser treatment, vitrectomy surgery, anti-VEGF agents and corticosteroids are the therapies that are available presently in the market for the treatment of DR.

\section{Laser Treatment}

Laser treatment depends on the disease severity. Laser photocoagulation was more effective for the treatment of DR. There are two types of laser treatment.

\section{Scatter or pan retinal photocoagulation}

Small amount of laser has been needed to treat DR. Laser should not be applied to the central part of the retina.

\section{Focal laser photocoagulation}

Laser photocoagulation leads the hypoxic condition in retina to anorexia.

\section{Vitrectomy surgery}

Complications of DR may be the interactions between the vitreous and retinal surface. Here vitreous gel is removed from the centre of eye. Local or general anaesthesia are used to stop bleeding from vitreous. In order to carryout vitrectomy, it needs overnight hospital stay. Eyes may take weeks to get recovered after treatment. Inflammation and infection is reduced by applying eye drops. If both eyes require vitrectomy, after the first eye has recovered second eye will be treated again (Harbour et al., 1996; Smiddy and Flynn., 1999; DRCRNWC., 2010). 


\section{Anti VEGF Treatment}

Anti-VEGF agents were helped in the retinal vascular permeability improvement, causes blood-retinal barrier breakdown, and finally results in retinal edema (Aiello et al., 1997). VEGF level is increased in DR. There are known 5 isoforms of VEGF. At present, pegaptanib (Macugen; Pfizer, Inc., New York, USA), (Cunningham et al., 2005; Gonza' lez et al., 2009), ranibizumab (Lucentis ${ }^{\circledR}$; Genentech, Inc., South San Francisco, California, USA) (Chun et al., 2006; Rosenfeld et al., 2006; Erfurth et al., 2014; Comyn et al., 2014), bevacizumab (Yanyali et al., 2007; Roh et al., 2008; Fang et al., 2008;) (Avastin ${ }^{\circledR}$; Genentech, Inc.), and VEGF Trap-Eye (Do et al., 2009; -108) (Regeneron Pharmaceuticals, Inc., Tarrytown, New York, USA).

\section{Corticosteroids}

Corticosteroids are used for various intraocular neovascular and edematous diseases, which includes certain diseases such as DME, PDR, neovascular glaucoma and chronic prephthisical ocular hypo tony (Paccola et al., 2008).

\section{Emerging therapies}

Treating DR was done by initiation of some of the biochemical mechanisms, the drugs which includes are aldose reductase inhibitors, PKC inhibitors, anti-inflammatory drugs, fenofibrate, somatostatin analogs, RAAS blockers, anti-oxidants and certain combination therapies.

\section{Aldose reductase inhibitor}

Newly developed inhibitors addressed more efficient action than older but in clinical testing which showed failure in the better management of DR (Sun et al., 2006).

\section{PKC Inhibitors}

When vascular endothelial cells were exposed to oxidative stress PKC activity also has been increased, which leads to the development diabetic micro vascular complications. Endothelial cell permeability, blood flow and angiogenesis are regulated by PKC (Taher et al., 1993; Huang et al., 1997).

Table 1: List of drugs and therapies that are currently available in the market for DR treatment.

\begin{tabular}{|c|c|c|c|c|c|c|}
\hline $\begin{array}{l}\text { Drug/ } \\
\text { Therapy }\end{array}$ & Mechanism of action & Grade & $\begin{array}{l}\text { Number of } \\
\text { patients } \\
\text { examined }\end{array}$ & $\begin{array}{l}\text { Study } \\
\text { Type }\end{array}$ & Outcomes & Phase \\
\hline Laser & $\begin{array}{l}\text { Destruction of retina and } \\
\text { supply oxygen, reduction in } \\
\text { VEGF expression }\end{array}$ & $\begin{array}{l}\text { PDR and } \\
\text { NPDR }\end{array}$ & 60 & Interventional & $\begin{array}{l}\text { Incidence of vision loss after } 1 \\
\text { yr. }\end{array}$ & Phase 3 \\
\hline \multirow[t]{2}{*}{$\begin{array}{l}\text { Vitrectomy } \\
\text { surgery }\end{array}$} & \multirow[t]{2}{*}{$\begin{array}{l}\text { Surgical removal of vitreous } \\
\text { gel }\end{array}$} & PDR & 347 & Randomized & $\begin{array}{l}\text { Persistent haemorrhage were } \\
\text { evaluated }\end{array}$ & Phase 3 \\
\hline & & PDR & 70 & Randomized & $\begin{array}{l}\text { Intraoperative bleedings and } \\
\text { intraoperative retinal breaks } \\
\text { was measured. }\end{array}$ & Phase 2 \\
\hline \multirow[t]{4}{*}{$\begin{array}{l}\text { Anti-VEGF } \\
\text { agents }\end{array}$} & $\begin{array}{l}\text { Pegaptanib (Inhibits the } \\
\text { VEGF from binding and } \\
\text { activating the VEGFR2 } \\
\text { receptor) }\end{array}$ & PDR & 30 & Non-Randomized & $\begin{array}{l}\text { To further establish the } \\
\text { efficacy of intra-vitreal } \\
\text { injections in the regression of } \\
\text { retinal neovascularisation } \\
\text { secondary as compared to } \\
\text { laser. }\end{array}$ & Phase 4 \\
\hline & $\begin{array}{l}\text { Bevacizumab (It binds and } \\
\text { inhibits the all isoforms of } \\
\text { human VEGF activity }\end{array}$ & $\begin{array}{l}\text { Severe } \\
\text { NPDR }\end{array}$ & 40 & Non-Randomized & $\begin{array}{l}\text { Evaluated Visual Acuity, } \\
\text { neovascularisation leakage } \\
\text { points and florescent } \\
\text { angiography }\end{array}$ & $\begin{array}{l}\text { Phase } 2 \& \\
\text { Phase } 3\end{array}$ \\
\hline & $\begin{array}{l}\text { Ranibizumab (Inhibits VEGF } \\
\text { A and activating the VEGF } 2 \\
\text { receptor }\end{array}$ & PDR & 20 & Randomized & $\begin{array}{l}\text { The improvement or worsening } \\
\text { of vision was measured }\end{array}$ & Phase2 \\
\hline & $\begin{array}{l}\text { Aflibercept (Have VEGF } \\
\text { binding sites) }\end{array}$ & PDR & 20 & Randomized & $\begin{array}{l}\text { Incidence and severity was } \\
\text { measured }\end{array}$ & $\begin{array}{l}\text { Phase2 \& } \\
\text { Phase3 }\end{array}$ \\
\hline \multirow[t]{3}{*}{ Corticosteroids } & $\begin{array}{l}\text { IVTA (Down regulating } \\
\text { matrix metalloproteinase } \\
\text { activation) }\end{array}$ & PDR & 60 & Randomized & $\begin{array}{l}\text { Visual acuity, no of treatments, } \\
\text { duration of efficacy was } \\
\text { measured }\end{array}$ & Phase1 \\
\hline & $\begin{array}{l}\text { Fluocinolone acetonide } \\
\text { (Inhibition of VEGF and anti- } \\
\text { inflammatory properties) }\end{array}$ & $\begin{array}{l}\text { DR \& } \\
\text { DME }\end{array}$ & 40 & Randomized & $\begin{array}{l}\text { Between group difference in } \\
\text { mean visual acuity change }\end{array}$ & Phase2 \\
\hline & $\begin{array}{l}\text { Dexamethasone (PKC } \\
\text { activation) }\end{array}$ & PDR & 100 & Randomized & Reoperation was needed & Phase2 \\
\hline
\end{tabular}


Table: 2: Emerging therapies for the better management of DR.

\begin{tabular}{|c|c|c|c|}
\hline Category & Drug & Mechanism of action & References \\
\hline reductase & Aspirin & Reduce VEGF expression & (Sun et al., 2006) \\
\hline \multirow[t]{2}{*}{ PKC inhibitors } & Ruboxistaurin mesylate & Inhibitor of PKC-1 and 2 receptors & The PKC-DRS group., 2005 \\
\hline & Pazopanib & $\begin{array}{l}\text { selective inhibitor of glycation that leads } \\
\text { to inhibition of VEGF and PEDF }\end{array}$ & Thakur et al., 2011 \\
\hline \multirow[t]{3}{*}{ Anti-inflammatory } & Etanercept, Fidarestat & $\begin{array}{l}\text { Intercellular } \quad \begin{array}{l}\text { adhesion } \\
\text { (ICAM1) expression can be reduced }\end{array} \\
\text { (IC) }\end{array}$ & Tsilimbaris et al., 2007, Kato et al., 2009 \\
\hline & Infliximab & $\begin{array}{l}\text { Block the inflammatory molecule } \\
\text { tumour necrosis factor } \alpha(\mathrm{TNF} \alpha) \text {. }\end{array}$ & Sfikakis et al., 2010 \\
\hline & ESBA105 & Anti TNF $\alpha$ & Ottiger et al., 2009 \\
\hline Fibrates & Fenofibrate & $\begin{array}{l}\text { VEGF inhibition, reduction of cytokines } \\
\text { levels, PKC activation }\end{array}$ & Cheung and Wong., 2008 \\
\hline Somatostatin analogs & Octreotide & PKC activation & Grant et al., 2000 \\
\hline \multirow[t]{4}{*}{ RAAS inhibitors } & Valsartan & Angiotensin I (ATI) receptor antagonist & \multirow{4}{*}{$\begin{array}{l}\text { Satofuka et al., } 2009 \\
\text { The EUCLID Study Group. } 1997\end{array}$} \\
\hline & Lisinopril & $\begin{array}{l}\text { Angiotensin-converting enzyme blocks } \\
\text { rennin-angiotensin system }\end{array}$ & \\
\hline & Candesartan & Angiotensin receptor blocker & \\
\hline & Losartan & ACE inhibition & \\
\hline \multirow[t]{5}{*}{ Anti-oxidants } & Ascorbic Acid & $\begin{array}{l}\text { Stimulates the retinal GSH reductase and } \\
\text { SOD activities inhibition }\end{array}$ & Chen., 2009 \\
\hline & Curcumin & Inhibition of VEGFs production & \\
\hline & Vitamin E & Prevention of lipid per oxidation & \\
\hline & Lipoic Acid & Reduction of VEGF expression & Clinicaltrials. Gov., 2016 \\
\hline & Resveratrol & Reduction of retinal oxidative stress & Kim et al., 2012 \\
\hline \multirow[t]{7}{*}{ Combination therapies } & Triamcinolone Acetonide & Intra-vitreal injection + Laser & Gillies et al., 2011 \\
\hline & Bevacizumab + Triamcinolone & Intra-vitreal injection & Paccola et al., 2008; Shimura et al., 2008; \\
\hline & Ranibizumab + Triamcinolone Acetonide & Intra-vitreal injection + Laser & \\
\hline & Bevacizumab & Intra-vitreal injection + Laser & Huang et al., 2009; Cho et al., 2009 \\
\hline & Pegaptanib & Intra-vitreal injection + Laser & Clinical trials Gov. 2015 \\
\hline & Aflibercept & Intra-vitreal injection + Laser & Clinical trials Gov. 2015 \\
\hline & Ranibizumab & Intra-vitreal injection + Laser & Brown et al., 2006 \\
\hline
\end{tabular}

\section{Anti-Inflammatory Agents}

Intraocular inflammation is the second mechanism for the DR development. For this reason non steroidal antiinflammatory (NSAIDS) agents were used for prostaglandins production inhibition (Sfikakis et al., 2005; Tsilimbaris et al., 2007).

\section{Fibrates}

Fibrates are lipid-lowering drugs which have been used often in dyslipidemia treatment. Reduction in total cholesterol, LDL, glycerides and increase in HDL levels are due to activation of alpha receptor (Keech et al., 2007; Dodson 2009).

\section{Somatostatin analogues}

Somatostatin is also known as a growth hormone inhibitor. It exists in two forms, one form has 14 amino acids and other has 28 amino acids. It shows that somatostatin prevents PDR progression, haemorrhage and it was used in laser and vitrectomy surgery in DR (McCombe et al., 1991; Grant et al., 2000; Boehm et al., 2001; Davis et al., 2001)

\section{RAAS blockers}

RAAS is involved in DR pathogenesis. Studies reported that increased levels of rennin, pro renin, and angiopoietin 2
(Ang 2) in the vitreous in patients with DR. As RAS blocker therapy may improve the condition of DR patients (Satofuka et al., 2009).

\section{Antioxidants}

Increase in oxidative stress due to hyperglycemia leads to high glucose level and other metabolic abnormalities. This results in the ROS overproduction. When there is no balance between their production and destruction it results in oxidative stress. The ROS formation was mediated by both enzymatic and nonenzymatic mechanisms. These are the some of the important antioxidants that are currently being studied (Bursell et al., 1999; Garcia-Medina et al., 2011; 139-141).

\section{Cryotherapy (Freezing)}

It may help in DR treatment. Laser can be performed after blood in vitreous layer settles down. In some cases retinal blood vessels may shrink and retina is bonded back of the eye.

\section{Combination Therapies}

Combination therapy has yielded better results than intravitreal monotherapy. The RESTORE study (SchmidtErfurth et al., 2014) showed a greater improvement in patients treated with both intra-vitreal and laser than in patients treated with monotherapy. 
Similarly, several studies reported an increased likelihood of an improvement in BCVA from baseline in patients treated with IVTA and laser versus only laser at 2 years. On the other hand, the READ2 study reported no significant difference in visual outcomes in the combination therapy group (Nguyen et al., 2010), although combination treatment provided an improvement in BCVA and a greater decrease in macular edema with fewer injections.

\section{Future Therapies}

The future DR treatment relies not only on the development of medications targeting molecules to the DR pathogenesis, but also on the development of novel delivery techniques. In order to maximize the effect of the treatment and minimize systemic adverse effects, targeted delivery of medication to the retina was ideal. Data's are emerging that medicine which is administered as eye drops are able to reach the retina than any other formulation with better therapeutic concentrations. Future development for therapies for DR treatments includes hepatocyte growth factor, matrix metalloproteinase-9 (MMP9), monocyte chemo tactic protein1 (MCP1), kallikrein, Ang2, and NFkB. Inhibition of hepatocyte growth factor and MMP9 may prevent DR or cause regression of PDR. Retinal neovascularisation was suppressed by NFkB inhibition (Yoshida et al., 1999). Retinal vascular permeability improvement was associated with Ang2 (Rangasamy et al., 2011), Kallikrein activation (Feener., 2010) and Hepatocyte growth factor (Nishimura et al., 1998). ). Increased level of MMP9 has been found in vitreous and retina of patients with diabetes (Jin et al., 2001).

DR and PDR regression can be prevented by these two molecules. As the exact mechanisms involved in the pathogenesis of DR are elucidated more therapeutic targets will emerge, and the armamentarium of treatment options for DR will expand greatly.

\section{CONCLUSION}

DR is which may lead to legal blindness and it is a major public health problem. Early detection through screening, educating the population and timely intervention may decrease the complications in the course of disease. As laser therapy is not that much effective, pharmacological treatments may provide alternative strategy for DR. Both intra-vitreal corticosteroids and intra-vitreal anti- VEGF agents are widely used in clinical settings Diabetic vitrectomy increased life quality by improving vision. Early treatment for vitrectomy showed cost- effective intervention. Fenofibrate treated patients showed reduction in retinal laser therapy. The role of combination therapies is yet to be determined .Finally it was shown that DR can be treated in earlier stages.

The ideal medication for the treatment of DR is fast acting, long lasting and above all, safe. As the development of DR is a multi factorial process, involving inflammation and ischemia, future therapies, especially combination therapies, targeting different pathways may lead to more favourable outcomes.
Financial support and sponsorship: Nil.

Conflict of Interests: There are no conflicts of interest

\section{REFERENCES}

Aiello LP. Perspectives on diabetic retinopathy. Am J Ophthalmol. 2003; 136: 122-135.

Armstrong D, Ueda T, Ueda T. Lipid hydroperoxide stimulates retinal neovascularization in rabbit retina through expression of tumor necrosis factor- $\alpha \alpha$, vascular endothelial growth factor and platelet-derived growth factor. Angiogenesis. 1998; 2 (1): 93-104.

Boehm BO, Lang GK, Jehle PM, Feldman B, Lang GE. Octreotide reduces vitreous hemorrhage and loss of visual acuity risk in patients with high-risk proliferative diabetic retinopathy. Horm Metab Res. 2001;33:300-6.

Brown DM, Kaiser PK, Michels M. Ranibizumab versus verteporfin for neovascular age-related macular degeneration. New England Journal of Medicine. 2006; 355 (14): 1432-1444, 2006.

Bursell SE, Clermont AC, Aiello LP, Aiello LM, Schlossman DK, Feener EP, et al. High-dose vitamin E supplementation normalizes retinal blood flow and creatinine clearance in patients with type 1 diabetes. Diabetes Care. 1999; 22:1245-51.

Chaturvedi N, Porta M, Klein R. Effect of candesartan on prevention (DIRECT-Prevent 1) and progression (DIRECT Protect 1) of retinopathy in type 1 diabetes: randomised, placebo-controlled trials. The Lancet. 2008; 372(9647):1394-1402.

Chen D. Novel antioxidants for treatment of diabetic retinopathy. 2009. SBIR.gov https://www.sbir.gov. (In press)

Cheung N, Wong TY. Fenofibrate and diabetic retinopathy. Lancet. 2008;371:721-2.

Chibber R, Molinatti PA, and Kohner EM. Intracellular protein glycation in cultured retinal capillary pericytes and endothelial cells exposed to high-glucose concentration. Cellular and Molecular Biology. 1999; 45(1):47-57.

Cho WB, Oh SB, Moon JW, Kim HC. Panretinal photocoagulation combined with intra-vitreal bevacizumab in high risk proliferative diabetic retinopathy. Retina. 2009; 29 (4): 516-522.

Chun DW, Heier JS, Topping TM, Duker JS, and Bankert JM. A pilot study of multiple intra-vitreal injections of ranibizumab in patients with center-involving clinically significant diabetic macular edema. Ophthalmology. 2006; 113 (10), 1706-1712

Clarke $\mathrm{M}$ and Dodson PM. PKC inhibition and diabetic microvascular complications. Best Practice and Research: Clinical Endocrinology and Metabolism. 2007; 21(4): 573-586.

Clinical trials Gov. Prospective, randomized, open Label, phase II study to assess efficacy and safety of Macugen ${ }^{\circledR}$ (Pegaptanib $0.3 \mathrm{mg}$ intravitreal injections) plus panretinal photocoagulation (PRP) and PRP (Monotherapy) in the treatment with high risk proliferative diabetic retinopathy. https://clinicaltrials.gov/ct2/show/NCT01281098. Last updated: March 18, 2015.

Clinical trials. Gov. Laser therapy combined with intravitreal aflibercept Vs intravitreal aflibercept monotherapy (LADAMO). https://clinicaltrials.gov/ct2/show/NCT02432547. Last updated June2, 2015.

Clinicaltrials. Gov. The use of alpha lipoic acid for the treatment and prevention of diabetic retinopathy (ALA-TPD). https://clinicaltrials.gov/ct2/show/NCT01880372. Last updated May 18, 2016.

Comyn O, Sivaprasad S, Peto T, Neveu MM, Holder GE, Xing W. A randomized trial to assess functional and structural effects of ranibizumab versus laser in diabetic macular edema (the LUCIDATE study). Am J Ophthalmol 2014;157: 960-70.

Coxon A, Bready J, Min H. Context-dependent role of angiopoietin-1 inhibition in the suppression of angiogenesis and tumor growth: implications for AMG 386, an angiopoietin- 1/2- neutralizing peptibody. Molecular Cancer therapeutics. 2010; 9 (10): 2641-2651 
Cunningham Jr ET, Adamis AP, Altaweel M. A phase II randomized double-masked trial of pegaptanib, an anti-vascular endothelial growth factor aptamer, for diabetic macular edema. Ophthalmology. 2005; 112 (10): 1747- 1757

Dagher Z, Park YS, Asnaghi V, Hoehn T, Gerhardinger C, Lorenzi M. Studies of rat and human retinas predict a role for the polyol pathway in human diabetic retinopathy. Diabetes 2004; 53: 2404-2411.

Davis MI, Wilson SH, Grant MB. The therapeutic problem of proliferative diabetic retinopathy: targeting somatostatin receptors. Horm Metab Res. 2001; 33:295-9.

Diabetes - type 2; NICECKS, July2010 (UK access only)

Do DV, Nguyen QD, Shah SM, Browning DJ, Haller JA, Chu K, Yang K, Cedarbaum JM, Vitti RL, Ingerman A, Campochiaro PA. An exploratory study of the safety, tolerability and bioactivity of a single intra-vitreal injection of vascular endothelial growth factor Trap-Eye in patients with diabetic macular oedema. Br. J. Ophthalmol. 2009;93 (2): 144-149.

Dodson PM. Management of diabetic retinopathy: could lipidlowering be a worthwhile treatment modality? Eye (Lond). 2009; 23:9971003.

Early Treatment Diabetic Retinopathy Study Research Group. Early photocoagulation for diabetic retinopathy. ETDRS report number 9. Ophthalmology. 1991; 98: 766

Eckardt KU. Erythropoietin and microvascular diabetic complications," Nephrology Dialysis Transplantation. 2009; 24 (2): 388 390

Fang X, Sakaguchi H, Gomi F, Oshima Y, Sawa M, Tsujikawa M, Ikuno Y, Kamei M, Kusaka S, Tano Y. Efficacy and safety of one intra-vitreal injection of bavacizumab in diabetic macular oedema. Acta Ophthalmol. 2008; 86 (7): 800-805.

Feener EP. Plasma kallikrein and diabetic macular edema. Curr Diab Rep. 2010;10:270-5.

Funatsu H, Yamashita H, Nakanishi Y, and Hori S. Angiotensin II and vascular endothelial growth factor in the vitreous fluid of patients with proliferative diabetic retinopathy. British Journal of Ophthalmology. 2002;86(3):311-315

Garcia-Medina JJ, Pinazo-Duran MD, Garcia-Medina M, Zanon-Moreno V, Pons-Vazquez S. A 5-year follow-up of antioxidant supplementation in type 2 diabetic retinopathy. Eur J Ophthalmol 2011; 21:637-43.

Gillies MC, McAllister IL, Zhu M, Wong W, Louis D, Arnold JJ, Wong TY. Intra-vitreal triamcinolone prior to laser treatment of diabetic macular edema: 24 month results of a randomized controlled trial. Ophthalmology. 2011;118:866-72.

Gonza' lez VH, Giuliari GP, Banda RM, Guel, DA. Intra-vitreal injection of pegaptanib sodium for proliferative diabetic retinopathy. Br. J. Ophthalmol. 2009; 93 (11): 1474-1478.

Grant MB, Mames RN, Fitzgerald C, Hazariwala KM, CooperDeHoff R, Caballero S, Estes KS. The efficacy of octreotide in the therapy of severe nonproliferative and early proliferative diabetic retinopathy: a randomized controlled study. Diabetes Care. 2000; 23:504-49.

Halliwell B and Gutteridge JMC. Role of free radicals and catalytic metal ions in human disease: an overview. Methods in Enzymology. 1990; 186:1-85

Hammes H. P, Martin S, Federlin K, Geisen K, and Brownlee M. Aminoguanidine treatment inhibits the development of experimental diabetic retinopathy. Proceedings of the National Academy of Sciences of the United States of America. 1991; 88(24): 11555-11558.

Haurigot V, Villacampa P, Ribera A. Increased intraocular insulin-like growth factor-I triggers blood-retinal barrier breakdown. The Journal of Biological Chemistry, 2009; 284(34): 22961-22969.

Huang Q, Yuan Y. Interaction of PKC and NOS in signal transduction of microvascular hyperpermeability. Am J Physiol. 1997; 273:H2442-H2451.

Huang YH, Yeh PT, Chen MS, Yang CH, Yang CM. Intravitreal bevacizumab and panretinal photocoagulation for proliferative diabetic retinopathy associated with vitreoushemorrhage. Retina. 2009; 29 (8):1134-1140
Hudson C, The clinical features and classification of diabetic retinopathy. Ophthalmic physiol opt 1996; 16(suppl. 2):S43-8

Hueber A, Wiedemann P, Esser P, and Heimann K. Basic fibrobroblast growth factor mRNA, bFgF peptide and FGF receptor in epiretinal membranes of intraocular proliferative disorders (PVR and PDR). International Ophthalmology. 1996; 20 (6): 345-350

International diabetes federation. Diabetes Atlas. diabetes atlas, $6^{\text {th }}$ edition, revision 2014. accessed at www.idf.org/

Jin M, Kashiwagi K, Iizuka Y, Tanaka Y, Imai M, Tsukahara S. Matrix metalloproteinases in human diabetic and nondiabetic vitreous. Retina. 2001;21:28-33

Kato N, Yashima S, Suzuki T, Nakayama Y, Jomori T. Longterm treatment with fidarestat suppresses the development of diabetic retinopathy in STZ induced diabetic rats. J Diabetic Complications 2003; 17:374-9.

Keech AC, Mitchell P, Summanen PA, O’Day J, Davis TM, Moffitt MS, et al. Effect of fenofibrate on the need for laser treatment for diabetic retinopathy (FIELD study): a randomised controlled trial. Lancet. 2007;370:1687-97.

Kilpatrick ES, Rigby AS, Atkin SL. The effect of glucose variability on the risk of micro vascular complications in type 1 diabetes. Diabetes Care 2006; 29: 1486-1490.

Kim YH. Resveratrol blocks diabetes induced early vascular lesions and vascular endothelial growth factor induction in mouse retinas. Acta Ophthalmol 2012; 90: e31-e37.

H. King, R.E. Albert, W.H. Herman, Global Burden of Diabetes, 1995-2025, prevalence, numerical estimates, and projections. Diabetes Care.1998; 21:1414-1431.

Klein BEK, Knudtson MD, Tsai MY, and Klein R.The relation of markers of inflammation and endothelial dysfunction to the prevalence and progression of diabetic retinopathy: Wisconsin epidemiologic study of diabetic retinopathy. Archives of Ophthalmology. 2009; 127(9):11751182.

Kohner EM. The retinal blood flow in diabetes. Diabete et Metabolisme. 1993; 19(5): 401-404.

Koya D and King GL. Protein kinase C activation and the developmentof diabetic complications. Diabetes, 1998; 47(6): 859-866.

Lee HS, Jun J, Jung E, Koo BA, Kim YS. Epigalloccatechin-3gallate inhibits ocular neovascularization and vascular permeability in human retinal pigment epithelial and human retinal microvascular endothelial cells via suppression of MMP-9 and VEGF activation. Molecules 2014; 19: 12150-12172.

Lev-Ran A, Hwang DL, Miller JD, Josefsberg Z. Excretion of epidermal growth factor (EGF) in diabetes. Clinica Chimica Acta, 1990; 192 (3): 201-206.

Lutty GA, J. Cao, and McLeod DS. Relationship of polymorphonuclear leukocytes to capillary dropout in the human diabetic choroid. American Journal of Pathology. 1997; 151(3): 707-714.

Mancia G. The association of hypertension and diabetes: prevalence, cardiovascular risk and protection by blood pressure reduction. Acta Diabetologica. 2005; 42(1): S17-S25.

Mates JM, Perez-Gomez C, Nunez de Castro I. Antioxidant enzymes and human diseases. Clinical Biochemistry. 1999; 32 (8): 595603

Mauer M, Zinman B, Gardiner R. Renal and retinal effects of enalapril and losartan in type 1 diabetes. The New England Journal of Medicine. 2009; 361 (1): 40-51.

McCombe M, Lightman S, Eckland DJ, Hamilton AM, Lightman SL. Effect of a long-acting somatostatin analogue (BIM23014) on proliferative diabetic retinopathy: a pilot study. Eye (Lond). 1991; 5:569-75.

Min SH, Lee TI, ChungYS, and Kim HK. Transforming growth factor- $\alpha \alpha$ levels in human aqueous humor of glaucomatous, diabetic and uveitic eyes. Korean Journal of Ophthalmology, 2006; 20 (3):162165.

Nguyen QD, Shah SM, Khwaja AA, Channa R, Hatef E, Do D. Twoyearm outcomes of the ranibizumab for edema of the macula in diabetes (READ2) study. Ophthalmology. 2010;117:2146-51. 
Masato nishimura, koji nakano, Masaji ushiyama, Akira nanbu, Ken ohtsuka, Hakuo takahashi, Manabu yoshimura. Increased serum concentrations of human hepatocyte growth factor in proliferative diabetic retinopathy. J Clin Endocrinol Metab. 1998;83:195-8.

Obrosova IG, Pacher P, Szabo C, Zsengeller Z, Hirooka H, Stevens MJ, Yorek MA. Aldose reductase inhibition counteracts oxidative-nitrosative stress and poly (ADP-ribose) polymerase activation in tissue sites for diabetes complications. Diabetes. 2005; 54: 234-242.

Ottiger M, Thiel MA, Feige U, Lichtlen P, Urech DM. Efficient intraocular penetration of topical anti-TNF-alpha single chain antibody (ESBA105) to anterior and posterior segment without penetration enhancer. Invest Ophthalmol Vis Sci 2009; 50: 779-86.

Paccola L, Costa RA, Folgosa MS, Barbosa JC, Scott IU, Jorge R. Intra-vitreal triamcinolone versus bevacizumab for treatment of refractory diabetic macular oedema (IBEME study). Br. J. Ophthalmol. 2008; 92 (1): 76-80.

Patel JI, Hykin PG, Gregor ZJ, Boulton M, Cree IA. Angiopoietin concentrations in diabetic retinopathy. British Journal of Ophthalmology. 2005; 89 (4): 480-483.

Peppa M, Uribarri J, Vlassara H. Glucose Advanced glycation end products, and diabetes complications: what is new and what works. Clinical Diabetes. 2003; 21(4): 186-187.

Porta M, Allione A. Current approaches and perspectives in the medical treatment of diabetic retinopathy. Pharmacol Ther.2004; 103: 167177.

Porta and Bandello, 2002. Diabetic Retinopathy a Clinical update. Diabetologia. 2002; 45:1617-1634.

Praidou A, Klangas I, Papakonstantinou E. Vitreous and serum levels of platelet-derived growth factor and their correlation in patients with proliferative diabetic retinopathy," Current Eye Research. 2009; 34 (2): $152-161$

Rangasamy S, Srinivasan R, Maestas J, McGuire P, Das A. A potential role of angiopoietin2 in the alteration of the blood retinal barrier in diabetic retinopathy. Invest Ophthalmol Vis Sci. 2011;52:3784-91.

Rechtman E, Harris A, Garzozi HJ, Ciulla TA. Pharmacologic therapies for diabetic retinopathy and diabetic macular edema. Clin. Ophthalmol. 2007;1: 383-391.

Roh, MI, Byeon, SH, Kwon, WO. Repeated intra-vitreal injection of bevacizumab for clinically significant diabetic macular edema. Retina. 2008; 28 (9): 1314-1318.

Rosenfeld PJ, Brown DM, Heier JS. Ranibizumab for neovascular age-related macular degeneration. New England Journal ofMedicine. 2006; 355 (14):1419-1431.

Satofuka S, Ichihara A, Nagai N, Noda K, Ozawa Y, Fukamizu A, et al. (Pro) rennin receptor mediated Signal transduction and tissue renin angiotensin system contribute to diabetes induced retinal inflammation. Diabetes. 2009;58:1625-33.

Schaumberg DA, Glynn RJ, Jenkins AJ, Lyons TJ, Rifai N, Manson JE, Ridker PM, Nathan DM. Effect of intensive glycemic control on levels of markers of inflammation in type 1 diabetes mellitus in the diabetes control and complications trial. Circulation. 2005; 111: 24462453.

SchmidtErfurth U, Lang GE, Holz FG, Schlingemann RO, Lanzetta P, Massin P, et al. Threeyear outcomes of individualized ranibizumab treatment in patients with diabetic macular edema: The RESTORE extension study. Ophthalmology. 2014;121:1045-53.

Schmidt-Erfurth U, Lang GE, Holz FG, Schlingemann RO, Lanzetta P, Massin P, et al. Three-year outcomes of individualized ranibizumab treatment in patients with diabetic macular edema: The RESTORE extension study. Ophthalmology. 2014;121:1045-53.

Schroder S, Palinski W, and Schmid-Schonbein GW. Activated monocytes and granulocytes, capillary nonperfusion, and neovascularization in diabetic retinopathy. American Journal of Pathology. 1991; 139 (1): 81-100.

Sfikakis PP, Grigoropoulos V, Emfietzoglou I. Infliximab for diabetic macular edema refractory to laser photocoagulation: a randomized, double-blind, placebo-controlled, cross-over, 32-week study. Diabetes Care. 2010; 33: 1523-8.
Sfikakis PP, Markomichelakis N, Theodossiadis GP, Grigoropoulos V, Katsilambros N, Theodossiadis PG. Regression of sight threatening macular edema in type 2 diabetes following treatment with the antitumor necrosis factor monoclonal antibody infliximab. Diabetes Care. $2005 ; 28: 445-7$.

Shimura M, Nakazawa $T$, Yasuda $K$, Shiono $T$, Iida $T$, Sakamoto T. Nishida K, Comparative therapy evaluation of intra-vitreal bevacizumab and triamcinolone acetonide on persistent diffuse diabetic macular edema. Am. J. Ophthalmol. 2008;145 (5), 854-861.

Simonson DC. Etiology and prevalence of hypertension in diabetic patients. Diabetes Care. 1998; 11(10): 821-827.

Sjølie AK, Klein R, Porta M. Effect of candesartan on progression and regression of retinopathy in type 2 diabetes (DIRECTProtect 2): a randomised placebo-controlled trial. The Lancet. 2008; 372(9647): 1385-1393

Smiddy WE, Flynn HW. Vitrectomy in the Management of Diabetic Retinopathy. Surv Ophthalmol 1999; 43(6): 491-507.

Spijkerman AMW, Gall MA, Tarnow L. Endothelial dysfunction and low-grade inflammation and the progression of retinopathy in type 2 diabetes. Diabetic Medicine. 2007; 24(9): 969-976.

Stitt AW, Jenkins AJ, and Cooper ME. Advanced glycation end products and diabetic complications. Expert Opinion on Investigational Drugs. 2002; 11 (9): 1205-1223.

Stratton IM, Cull CA, Adler AI, Matthews DR, Neil HA, Holman RR. Additive effects of glycaemia and blood pressure exposure on risk of complications in type 2 diabetes: a prospective observational study (UKPDS 75). Diabetologia. 2006; 49: 1761- 1769.

Sun W, Oates PJ, Coutcher JB, Gerhardinger C, Lorenzi M. A selective aldose reductase inhibitor of a new structural class prevents or reverses early retinal abnormalities in experimental diabetic retinopathy. Diabetes. 2006; 55:2757-62.

Taher M, Garcia J, Natarajan V.Hydroperoxide-induced diacylglycerol formation and protein kinase $\mathrm{C}$ activation in vascular endothelial cells. Arch Biochem Biophys .1993; 303:260-266.

Thakur A'Scheinman RI, Rao VR, Kompella UB. Pazopanib, a multitargeted tyrosine kinase inhibitor, reduces diabetic retinal vascular leukostasis and leakage. Microvasc Res. 2011; 82(3):346-50.

The EUCLID Study Group. Randomised placebo controlled trial of lisinopril in normotensive patients with insulin-dependent diabetes and normoalbuminuria or microalbuminuria. Lancet 1997; 349: 17871792.

The PKC-DRS group. The effect of ruboxistaurin on visual loss in patients with moderately severe to very severe non-proliferative diabetic retinopathy: intial results of the protein kinase $\mathrm{C}$ beta inhibitor diabetic retinopathy study (PKC-DRS) multicenter randomized clinical trial. Diabetes 2005; 54: 2188-97.

Tsilimbaris MK, Panagiotoglou TD, Charisis SK, Anastasakis A, Krikonis TS, Christodoulakis E. The use of intra-vitreal etanercept in diabetic macular oedema. Semin Ophthalmol. 2007;22:75-9.

Tsilimbaris MK, Panagiotoglou TD, Charisis SK. The use of intravitreal etanercept in diabetic macular edema. Semin Ophthalmol 2007; 22(2):75-9.

Van den Enden MK, Nyengaard JR, Ostrow E, Burgan JH, and Williamson JR. Elevated glucose levels increase retinal glycolysis and sorbitol pathway metabolism: implications for diabetic retinopathy. Investigative Ophthalmology and Visual Science. 1995; 36 (8): 16751685. 1995.

Van Hecke MV, Dekker JM, Nijpels G. Inflammation and endothelial dysfunction are associated with retinopathy: the Hoorn study. Diabetologia. 2005; 48 (7):1300-1306.

Wang QJ. PKD at the crossroads of DAG and PKC signalling. Trends in Pharmacological Sciences. 2006; 27 (6): 317-323.

Wang Y, Fawzi A, Tan O, Gil-Flamer J, Huaung D, Retinal blood flow detection in diabetic patients by Doppler Fourier domain optical coherence tomography. Opt Express 2009; 17:4061-73

Wilkinson-Berka JL, Wraight C, and Werther G. The role of growth hormone, insulin-like growth factor and somatostatin in diabetic retinopathy. Current Medicinal Chemistry. 2006; 13 (27): 3307-3317. 
Wilkinson-Berka JL. Angiotensin and diabetic retinopathy. International Journal of Biochemistry and Cell Biology. 2006; 38(5-6): $752-765$.

Yanyali A, Aytug B, Horozoglu F, Nohutcu AF. Bevacizumab (Avastin $\left({ }^{\circledR}\right)$ for diabetic macular edema in previously vitrectomized eyes. Am. J. Ophthalmol.2007; 144 (1): 124-126.

Yoshida A, Yoshida S, Ishibashi T, Kuwano M, Inomata $\mathrm{H}$. Suppression of retinal neovascularization by the NFkappaB inhibitor pyrrolidine dithiocarbamate in mice. Invest Ophthalmol Vis Sci. 1999;40:1624-9.

Zong H, Ward M, Stitt AW. AGEs, RAGE, and diabetic retinopathy. Current Diabetes Reports. 2011; 11(4): 244-252.

How to cite this article:

Elakkiya M, Selvaraj K, Kuppuswamy G. Current and Emerging Therapies for the Management of Diabetic Retinopathy. J App

Pharm Sci, 2017; 7 (09): 243-251. 